\title{
Gulsott hos nyfødte kan være farligere enn du tror
}

Helsepersonell må vite om risikofaktorene og ta bekymringsmeldinger fra foreldre på alvor.

\section{Forfatter}

Thor Willy Ruud Hansen

Professor emeritus

Barne- og ungdomsklinikken, Oslo universitetssykehus og Institutt for klinisk medisin, Det medisinske fakultet, Universitetet i Oslo

Barnesykdom Nyfødt gulsott

Sykepleien 2019 107(77075)(e-77075)

DOI: https://doi.org/10.4220/Sykepleiens.2019.77075

\section{Hovedbudskap}

Gulsott er et vanlig fysiologisk funn hos nyfødte, men høye bilirubinverdier og risikofaktorer hos barnet kan føre til invalidiserende hjerneskade. Gulsott er ufarlig for de fleste. Derfor er det lett å overse de få nyfødte som kan få alvorlig skade. I de siste 5-10 årene har man sett to tilfeller av kjerneikterus i Norge. Oppfølgingen av det nyfødte barnet svikter etter utskrivning. Derfor minner jeg her om de viktigste poengene som gjelder risiko og oppfølging av nyfødte med gulsott.

Hver dag blir nyfødte barn i Norge undersøkt og behandlet for gulsott. Hvis vi går ut fra at omkring 5 prosent av friske, nyfødte barn på barselposter og 25 prosent av dem som er innlagt på en nyfødtavdeling, får fototerapi under oppholdet, er det over 4000 hvert år som får behandling for gulsott (1). 
Enda flere nyfødte blir undersøkt og testet, men fordi bilirubinverdiene deres (TSB, total serumbilirubin eller $\mathrm{TcB}$, transkutan bilirubin) er under grensene som defineres i de norske retningslinjene, trenger de ikke behandling (2).

Med utgangspunkt i norske tall (1) har jeg regnet ut at det gis mer enn 40000 timer fototerapi hvert år på norske nyfødtavdelinger. Vi kjenner ikke tallene for varigheten av lysbehandling ved norske barselavdelinger, men det er rimelig å anta 2,5 døgn i snitt for hvert behandlet barn. Det tilsvarer 160000 timer per år.

Med en såpass betydelig behandlingsinnsats er det ikke urimelig at noen spør hva man får igjen for innsatsen i arbeid og penger, hva det betyr at barnet er atskilt fra moren under behandlingen, og hvorvidt det er noen farlige bivirkninger av behandlingen.

\section{Lite grunnlag for evidens}

I en tid da evidensbasert medisin er det ideelle grunnlaget for vår behandling av pasientene, er det beklemmende å innrømme at grunnlaget for behandlingsgrensene er spinkelt, i hvert fall målt med vår tids standard. Dessverre vil det aldri bli mulig å gjøre randomiserte undersøkelser for å finne svarene.

Grunnene til dette er flere: Kjerneikterus er svært sjelden, bare 1:600 000 i Norge i perioden 2005-2014 (1). Det ville krevet randomisering av flere hundre millioner barn, noe som rent praktisk er umulig. En annen grunn er at det varierer hvor sårbare barn er med tanke på bilirubinvirkningene på hjernen. En tredje årsak er at vi har begrenset kunnskap om disse forholdene. 
Sist, men ikke minst, å gjøre en slik undersøkelse når det eneste målbare resultatet er barn med hjerneskade, som kunne vært unngått, er selvfølgelig etisk helt utenkelig. Hvis vi kunne finne en måte å måle hvorvidt hjernepåvirkningen nærmet seg et farepunkt, ville det kanskje sett annerledes ut.

\section{Kjerneikterus}

Kjerneikterus innebærer en varig skade av hjernens basalganglier og enkelte hjernenervekjerner. Tilstanden oppstår når bilirubin trenger inn i hjernen ved uttalt hyperbilirubinemi, ofte kombinert med risikofaktorer som gjør blod-hjerne-barrieren mer gjennomtrengelig og/eller hjernevevet mer sårbart.

Jeg kjenner til to tilfeller av kjerneikterus i Norge siden årtusenskiftet. Det ene er publisert, og det andre kjenner jeg bare av omtale (3). Dessuten er det beskrevet noen få tilfeller der barn ble lagt inn på sykehus med ekstrem gulsott og tegn på akutt bilirubinpåvirkning av hjernen, men der barna ble berget med raske og aggressive behandlingstiltak (4).

Felles for disse barna, og for flertallet av barn med kjerneikterus, er at de var utskrevet fra sykehuset, og bekymringsmeldinger fra foreldrene til helsepersonellet ble ikke tatt på alvor. Dette er nettopp beskrevet av Rennie og medarbeidere i England (5).

\section{Risikofaktorer}

Alle ansatte på barsel- og nyfødtavdelinger i Norge har derfor en felles utfordring når det gjelder gulsott hos nyfødte: å huske på at selv om nyfødtgulsott er en normaltilstand hos de fleste, finnes det ganske mange barn med tilleggsfaktorer som ikke er normale. Disse risikofaktorene ser vi som regel ikke utenpå barnet. 
De viktigste risikofaktorene er listet under punkt $1 \mathrm{i}$ faktaboksen under. Alle vi som steller med nyfødte på barsel- og nyfødtposter, må kunne denne lille listen på rams. Punktet som det trolig er lettest å overse, er punkt 1d, familiehistorien. Familiehistorien finnes ikke alltid i journalen, og da må vi spørre foreldrene.

\section{三 «Risikofaktorene ser vi som regel ikke utenpå barnet.»}

Et forslag som kanskje kan diskuteres på møter på de ulike barselpostene, er å ha listen eller hele faktaboksen hengende lett synlig der man undersøker barnet før utskrivningen, og der man gir lysbehandlingen.

\section{Nøkkelpunkter i nasjonale retningslinjer for gulsott hos nyfødte}

\section{Risikofaktorer å tenke på ved utskrivning:}

- synlig gulsott i første levedøgn

- blodgruppeuforlikelighet

- afrikanske og østasiatiske barn

- familiehistorie for gulsott eller hemolytisk sykdom

- gestasjonsalder $<37$ uker

- fraktur eller større hematomer

- hjemreise før 72 timer

Vurder risikoen for at barnet kan utvikle gulsott etter utskrivningen. Ta eventuelt prøver, transkutanmåling (TcB) eller blodprøve-TSB og plott på gulsottskjemaet, planlegg oppfølging og kontroll, og gi foreldrene informasjonsbrosjyren. 
2. Når foreldrene ringer etter

utskrivningen og er bekymret for gulsott:

- Alle skal få beskjed om å komme rett til avdelingen eller posten for vurdering av gulsotten og barnets tilstand.

- Ingen utsettelse til neste dag eller andre råd/forslag som forsinker.

- Ingen henvisning til helsestasjonen eller fastlegen.

- Hvis barnet ved ankomsten er lett eller moderat ikterisk:

- Ta TcB eller TSB, og plott resultatet på gulsottskjemaet.

- Vurder og planlegg videre oppfølging eller behandling ut fra hvor barnets verdi ligger i forhold til behandlingsgrensen.

3. Hvis barnet ved ankomsten er veldig ikterisk og/eller har nevrologiske symptomer eller tegn:

- Barnet legges straks i intensiv fototerapi (ikke vent på prøvetaking eller prøveresultater).

- Tilkall barnelege eller lege for snarlig undersøkelse og vurdering. 

4. Selv ved tegn på akutt
hjernepåvirkning kan tilstanden noen
ganger reverseres ved intensiv fototerapi,
eventuelt supplert med intravenøst
immunglobulin hvis det er holdepunkter for
blodgruppeuforlikelighet.
Utskiftningstransfusjon bør nesten alltid
utføres for å oppnå raskest mulig reduksjon
av TSB. Lysbehandling bør fortsette helt
frem til en eventuell utskiftning begynner og
kan gjerne fortsette med lysmatte eller -vest
også under prosedyren.

\section{Tidlig utskrivning}

Det blir stadig vanligere å skrive ut mor og barn tidlig fra barsel- og fødeavdelingen. Diskusjonen om tidlig utskrivning skal jeg ikke ta her. Jeg vil heller minne om at når barnet blir skrevet ut fra sykehuset etter ett til to levedøgn, har vi flyttet den viktigste delen av omstillingsprosessen som gjelder bilirubin og gulsott, til hjemmet.

I hjemmet ser helsepersonellet ikke lenger barnet, noe som betyr at vi må ha en veldig lav terskel for å ta barnet inn igjen på sykehuset til vurdering dersom foreldrene kontakter oss med spørsmål.

På side 2 i det norske bilirubinskjemaet sies dette veldig tydelig: «Foreldre som ringer og er bekymret for at et nyfødt barn har gulsott og samtidig er slapp eller spiser dårlig, skal få beskjed om å komme direkte til barsel-/nyfødtposten. Det skal ikke gis råd per telefon som fører til forsinkelser, og helsestasjonen skal ikke involveres i dette.» (6)

Jeg er fristet til å si at vi burde stryke «slapp eller spiser dårlig» fra skjemaet, fordi det innebærer at både foreldrene og helsepersonellet må utøve et skjønn som kan bli helt galt.

\section{Feil og farlige råd}


Dessverre har flere foreldre fortalt meg at når de har ringt til sykehuset, har de fått svar som har ført til forsinket reinnleggelse av barnet. Forsinket reinnleggelse av barnet går også igjen som en feil i den ferske engelske undersøkelsen som er nevnt tidligere (5).

Min erfaring er at foreldrene får slike klassiske svar når de melder sin bekymring om barnet til helsepersonellet: «Gulsott er ikke noe å bekymre seg for», «dagslys og hyppige måltider vil hjelpe» eller «det holder å legge barnet i vinduet».

\section{三 «Flere foreldre har fortalt meg at når de har ringt til sykehuset, har de fått svar som har ført til forsinket reinnleggelse av barnet.»}

Det er helt sant at gulsott som oftest ikke er noe å bekymre seg for, og at hyppige måltider over tid vil kunne bidra til å redusere gulsotten, men du kan ikke vite om det er sant for akkurat dette barnet når du ikke ser barnet selv.

Det er riktig at sollys under kontrollerte betingelser kan avhjelpe gulsott, men lysforholdene i norske vinduer er så uforutsigbare og variable at et slikt råd ikke bare er unyttig, men direkte farlig. I Norge har vi hatt nasjonale retningslinjer for behandling av gulsott hos nyfødte siden 2006 (2), og retningslinjene ble sist revidert for et par år siden (6).

\section{Veiledningsskjema}

Skjemaet «Norsk veileder for behandling av gulsott hos nyfødte» består av en forside med en grafisk framstilling av grensene for behandling og en bakside med tekst som forklarer bakgrunn og detaljer for teksten på side 1 (6). 
Alle som skal ha ansvaret for nyfødte ved norske barsel- og nyfødtposter, må kjenne dette skjemaet. Det vil si at de må forstå hvordan de skal føre inn TSBverdier på side 1 og ha lest og må kunne innholdet på side 2 i skjemaet, slik at de har en klar forståelse for hva vi som undersøker og behandler barna, gjør og hvorfor vi gjør det.

\section{三 «Alle som skal ha ansvaret for nyfødte ved norske barsel- og nyfødtposter, må kjenne dette veiledningsskjemaet.»}

Da skjemaet sist ble revidert, supplerte arbeidsgruppen i Norsk barnelegeforening hovedskjemaet med tre dokumenter som gir grundigere forklaringer om diagnostikk og behandling generelt:

- Gulsott hos nyfødte - diagnostikk og behandling

- Gulsott som varer $>2$ uker og morsmelkassosiert gulsott - diagnostikk og behandling

- Gulsott og blodgruppeimmunisering, intravenøst immunglobulin og utskiftningstransfusjon

På nettsiden der skjemaet ligger, finnes også lenke til en informasjonsbrosjyre for foreldrene. Brosjyren er skrevet både på norsk og engelsk (6).

\section{Viktig ved alvorlig gulsott}

De aller fleste barn som i dag rammes av kjerneikterus i vår del av verden, har vært skrevet ut fra en barseleller nyfødtavdeling og legges inn igjen med alvorlig gulsott. Det viser hvor viktig det er at helsearbeidere i Norge har klare regler for å

- vurdere barnets risiko for alvorlig gulsott før barnet skrives ut (se punkt $1 \mathrm{i}$ faktaboksen),

- ha lav terskel for å ta barn som er skrevet ut, inn igjen til vurdering, og 
- fjerne alle faktorer som lager forsinkelser ved mottak og eventuell behandling.

Dersom et barn kommer tilbake til vurdering og viser seg å ha alvorlig gulsott, spesielt hvis barnet har nevrologiske tegn på hjernepåvirkning som kramper eller bakoverbøyd rygg og nakke (opistotonos) er det viktig å handle raskt (se punkt 3 i faktaboksen).

\section{三 «Behandle først, så ta blodprøve!»}

Det første du må gjøre, er å kle barnet helt nakent og straks legge det i lyskasse. Hvis lysstyrken kan justeres, setter du den på høyeste styrke og senker lyskilden nærmest mulig barnet, gjerne ned til 10-20 $\mathrm{cm}$. Det er viktig med høy lysstyrke og lyskilden nær barnet fordi lyset begynner å virke med én gang og omdanner bilirubinmolekylet til vannløselig form.

Deretter må du straks tilkalle vakthavende barnelege og samtidig bestille blodprøve til TSB.

NB! Du skal ikke vente på TSB-resultatet før behandlingen starter - behandle først, så ta blodprøve!

Mens sykepleieren venter på lege og bioingeniør, sjekker vedkommende svangerskaps- og fødejournalen for opplysninger om morens og barnets blodgrupper, direkte antiglobulintest (DAT), andre prøver på blodgruppeuforlikelighet og ytterligere risikofaktorer (se punkt $1 \mathrm{i}$ faktaboksen).

Hvis opplysninger om blodgruppe og DAT mangler, må disse testene tas samtidig med TSB-prøven. Det er viktig å fortsette med intens lysbehandling frem til prøvesvar og andre opplysninger foreligger og legen som har undersøkt barnet, kan ta stilling til videre behandling og prøvetaking.

\section{Referanser}


1. Mreihil K, Benth JS, Stensrud HJ, Nakstad B, Hansen TW, the Norwegian NICU Phototherapy Study Group, et al. Phototherapy is commonly used for neonatal jaundice but greater control is needed to avoid toxicity in the most vulnerable infants. Acta Paediatr. 2018;107(4):611-9. DOI: 10.1111/apa.14141.

2. Bratlid D, Nakstad B, Hansen TW. National guidelines for treatment of jaundice in the newborn. Acta Paediatr. 2011;100(4):499-505. DOI: 10.1111/j.1651-2227.2010.02104.x.

3. Smerud O-J, Solevåg AL, Hansen TW, Grønn M. 14 dager gammel gutt med gulsott og apnoeanfall. Tidsskr Nor Legeforen. 2015;135:2167-70.

4. Hansen TW, Nietsch L, Norman E, Bjerre JV, Hascoet JM, Mreihil K, et al. Reversibility of acute intermediate phase bilirubin encephalopathy. Acta Paediatr. 2009;98(10):1689-94. DOI: 10.1111/j.16512227.2009.01409.x.

5. Rennie JM, Beer J, Upton M. Learning from claims: hyperbilirubinaemia and kernicterus. Arch Dis Child Fetal Neonatal Ed. 2019;104(2):F202-4. DOI: 10.1136/archdischild-2017-314622.

6. Norsk barnelegeforening. Norsk veileder for behandling av gulsott hos nyfødte [internett]. Oslo: Den norske legeforening; april 2016 [oppdatert 18.05.2016, sitert 06.05.2019]. Tilgjengelig fra: https://legeforeningen.no/Fagmed/Norskbarnelegeforening/Nasjonale-retningslinjer-ogprosedyrer/Norsk-veileder-for-behandling-av-gulsotthos-nyfodte/. 